Saudi Journal of Business and Management Studies Abbreviated Key Title: Saudi J Bus Manag Stud ISSN 2415-6663 (Print) |ISSN 2415-6671 (Online) Scholars Middle East Publishers, Dubai, United Arab Emirates Journal homepage: http://scholarsmepub.com/sjbms/

Original Research Article

\title{
Implications of Illegal Gold Mining on the Household Economy and the Environment
}

\author{
Endang Solichin* \\ Department of Economic Education, STKIP YPM Bangko, Indonesia
}

DOI: $10.36348 /$ sjbms.2020.v05i01.009

| Received: 13.01.2020 | Accepted: 20.01.2020 | Published: 22.01.2020

*Corresponding author: Endang Solichin

\section{Abstract}

This study aims to determine the implications of Illegal gold mining carried out by the community in Perentak village, Merangin Regency. The research method carried out is a qualitative method with a focus of attention on the household economy of rural communities and the environment, for that researchers hold interviews and discussions with communities in Perentak village and observe environmental changes. The results of the study found that the presence of Illegal gold mining conducted by the Perentak villagers had positive implications for the improvement of the household economy in the short term, but in the long term along with environmental changes as a result of the addition of gold without a permit had a negative impact on the environment which also had negative implications on the household economy.

Keywords: Illegal gold mining, economy, environment.

Copyright @ 2020: This is an open-access article distributed under the terms of the Creative Commons Attribution license which permits unrestricted use, distribution, and reproduction in any medium for non-commercial use (NonCommercial, or CC-BY-NC) provided the original author and source are credited.

\section{INTRODUCTION}

The rise of Illegal gold mining in Merangin district has caused concern by various parties because of its impact on environmental damage, water pollution, destroying productive rice fields, destroying the icon of tourism which is a local unity and other social problems.

The area which is now an Illegal gold mining area, originally was a green and attractive productive paddy field with the presence of water and river windmills so that it was a tourist attraction for tourists, but now it has been buried by mining lands and pools as puddles as due to the excavation it became an arid sight.

The entrepreneurs who provided heavy equipment and the local community volunteered to release their land which was productive land to be used as a gold mining quarry, so that the community in the short term received a substantial amount of money, averaging a hundred million per square meter price, this which makes the local people tempted by instant income on the other hand those who used to work in the fields switch jobs to become workers in the gold mining business without permission. Illegal gold mining activities in Perentak village are not only in paddy fields or areas, but have already entered residents' settlement areas. Local residents seemed to compete to do the prohibited activities without thinking about the impact of environmental pollution

The government, in this case the police, is having difficulty banning gold mining activities without this permit, because this has become a quite complicated social problem. On one side of this Illegal gold mining activity is prohibited by the government because of its impact on the environment including water pollution due to the use of the most dangerous substances namely mercury or mercury used to purify gold which can infiltrate tissues in the body resulting in damaged tissues and organs, deformed fetuses and low intellect. Water quality research by the Jambi Regional Environment Agency in April 2014 at 16 points found that the Batanghari category is now heavily polluted (Class D), allegedly due to unlicensed Gold Mining waste water [1]. 
While community members really want this activity because it can bring in large amounts of money in a short period of time, therefore the community members often take the fight against police officers related to the raids conducted, so it is not uncommon for police officers to deal with residents. Illegal gold mining activities are often driven by capital owners and backed up by influential people, so that it becomes a unique game because it is associated with various interests of certain parties.

\section{LITERATURE REVIEW}

Basically, before an area can be explored and exploited for mining, the area must first be included in the Mining Area. Mining Areas are areas that have mineral and / or coal potential and are not bound by government administrative boundaries that are part of national spatial planning [2]. The determination of the mining area is determined by the local government and consults with the House of Representatives.

Illegal gold mining activities are gold mining activities carried out either by individuals, groups of people, companies or foundations whose legal entities do not have licenses from the central or regional government in accordance with applicable laws.

There are several problems in gold mining activities without a permit, including: 1 . Work safety is not guaranteed, due to the use of toxic chemicals such as cyanide and mercury used by miners in processing gold ore. 2. The miners work with very simple techniques that are traditionally learned that were inherited from their ancestors.

Unauthorized gold mining activities carried out by the local community have resulted in an unharmonious relationship between official mining which has obtained a permit from the local community. On the other hand, the community's ignorance of the laws and regulations that apply in the mining sector as well as the weakness of the laws and regulations in the mining sector are reflected in the weak alignments towards the interests of the wider community.

Limited employment opportunities and business opportunities according to the level of expertise or skills of the grassroots, poverty in various ways such as economic poverty, low knowledge and skills, and a prolonged economic crisis gave birth to unemployment. These factors are driving the community in the village to conduct gold mining business activities without a permit with a very high risk of personal safety because of the risk of using toxic chemicals such as mercury. On the other hand they are dealing with the authorities who are responsible for mining without permission, so that conflicts often occur between the police and villagers who own land.
Exploitation of natural resources by Illegal gold mining that is carried out on a large scale and not in accordance with operational standards results in environmental degradation and damage. Changes in the environment around mining that are not done wisely have a negative impact on farmers who have land around the mine [3]. Besides that, the implications of Illegal gold mining not only damage the ecology and environment, but also disturbed the social community. The social impact of mining causes damage to the social relations that have been fostered between community groups in an area such as suspicion of mutual suspicion, communication between residents and village officials that are often not in line and so forth [4].

Illegal gold mining is a very profitable and attractive business. The rise in illegal gold mining has led to a statistically significant increase in violence, as measured by the rate of killings and slaughter victims, gold is believed to be the new engine in the Colombian conflict [5]. On the other hand shows that Illegal gold mining has a positive impact in improving people's lives in the form of work, generating income and meeting health, education needs for families [6].

\section{METHOD}

The method used in this study is a qualitative method by tracing and observing unlicensed gold mining activities in Perentak village, Pangkalan Jambu district, Merangin District with a focus on household economics and the environment, to obtain information from researchers conducting discussions and interviews with local communities, and make observations on the effects of environmental changes in Perentak village.

\section{Empirical data and analysis}

Perentak Village is located in Pangkalan Jambu Subdistrict, Merangin Regency, its beautiful natural environment with extensive village rice fields, along the river flow, there are many windmills that function to raise water to the rice field area to make a very beautiful sight so that it attracts the community to visit it as a local tourist area. The results of these rice fields are able to meet the needs of the local community even they are able to sell outside the village area.

The existence of unlicensed gold mining has changed people's thinking patterns and behavior because it provides fantastic expectations that are more profitable than traditional rice cultivation. Instant thinking patterns to be able to achieve great profits have encouraged the community to roll in to conduct gold mining illegally, they changed the pattern of work from working in the fields to working as a gold miner who can make money quickly. Productive land is no longer planted with rice but they give it up to mining businesses in return for an average of one hundred million square meters, a very lucrative reward, while they work in the illegal gold mining business. 
The rise of this illegal gold mining business has a serious impact on the environment, productive land has been turned into a mining area, puddles formerly excavated and rocks scattered because the miners do not rehabilitate them after mining, the river has become flat and dry and as a result when it rains there flash floods that inundate residential areas and cause property and even fatalities.

The use of chemicals such as cyanide and mercury is very influential on water quality, water becomes polluted with mercury which is very dangerous for public health which can infiltrate tissues in the body so that organs become damaged, the fetus can be deformed and IQ can become idiots. The use of heavy equipment used in mining greatly affects the air quality so that the $\mathrm{CO} 2$ content becomes high and causes the air to become very hot in the region, so the village which was once cool with a beautiful panorama decorated with waterwheels to flow through the rice fields into a barren full with a pile of stones and puddles accompanied by very hot air.

This condition is a serious threat to the future survival of the community both in terms of the environment, residential areas and the economy of rural communities because productive land for rice fields has turned into a barren and barren land.

\section{DISCUSSION}

Illegal gold mining in Perentak village in the short term provides a large income for the community but in the long run it has an impact on environmental damage where productive lands are damaged, so that in the long run it has an impact on decreasing the level of income when the mining area is exhausted while the land becomes no productive again.

Illegal gold mining is a criminal offense as regulated in articles 158 and 160 of Law Number 4 of 2009 concerning mineral and coal mining, but law enforcement has become a dilemma due to the existence of unlicensed mining related to social problems and the existence of poor communities in the mining area, even $77 \%$ of unlicensed miners experienced an increase in welfare as a result of unlicensed mining activities [7].

Gold mining without this permit has multi dimensions, both from the legal, social, poverty, and environmental aspects, therefore the treaty must also look at various dimensions so as not to invite new, more complicated problems, but if this condition is not immediately sought a solution will affect the worsening economy of the Perentak village community because the community no longer earns income, besides that the environment will be increasingly damaged so it is necessary to immediately empower the community's economy and empowerment of the potential that has been sidelined.
Empowerment of the village community Perentak is the best solution to save the environment and economy of the village community so that there needs to be assistance from a team that is expert in their fields, and the empowerment issues that will be carried out must be based on local wisdom. Research related to this needs to be done to find out the productive local potentials to be developed that can sustain the economy of rural communities on one side and environmental preservation on the other.

One form of empowerment that has the potential to increase community income is the conservation and cultivation of semah fish. Semah fish are freshwater fish that have high economic value, but the population has decreased dramatically and is extinct due to habitat destruction due to illegal gold mining. Conservation efforts are very important to prevent the extinction of semah fish while increasing community income. Assistance in community empowerment needs to be carried out by several experts in their fields such as education and fish farming skills, increased production and business management, training in spawning techniques, training in making feed, developing semah fish ecotourism and entrepreneurship training.

Semah fish has high economic value as consumption fish or ornamental fish as commodity, Semah fish price reaches Rp. 150,000 up to Rp. 200,000 per $\mathrm{kg}$, even in Malaysia it can reach 300 ringgit per $\mathrm{kg}$ or around Rp. 750,000 per kg [8]. Demand for Semah fish continues to increase but is not balanced with adequate production because most Semah fish are natural catches in the sense that they are not cultivated.

\section{CONCLUSION}

Implications of Illegal gold mining in the short term have a positive impact because with the lively mining business, the higher the level of community income, resulting in an increase in the welfare of the community around the mining area, especially for those who own land, but in the long run when the mining area is exhausted, then the community has no more income, because environmental damage has no productive land.

From the aspect of law enforcement of gold mining without a permit, this is very dilemative because it has multidimential aspects such as social, economic and legal aspects, which involve employment, poverty and lawlessness issues, so there needs to be policies that are able to accommodate complex problems and multidimensional. Efforts to empower the community by raising local wisdom become an important issue, especially in terms of community economic distinction, for this reason, it is necessary to pay attention to the economic potentials based on local wisdom to be appointed as targets in empowerment that can provide a comparative advantage for Perentak village. 


\section{REFERENCE}

1. Tambunan, I. (2014). Minum air merkuri di Batanghari. https://sains.kompas.com/read/2014/09/1524363/ Minum.Air.Merkuri.di.Batanghari. [diakses pada tanggal 20 Mei 2019]

2. Undang-Undang Nomor 4 Tahun 2009 tentang Pertambangan Mineral dan Batubara.

3. Febrianti, E. P. (2010). Analisis Ekonomi dan Keberlanjutan Usahatani Kopi di Kawasan Hutan Kabupaten Lampung Barat. Desertasi Pascasarjana UGM.

4. Petkova, V., Lockie, S., Rolfe, J., \& Ivanova, G. (2009). Mining developments and social impacts on communities: Bowen Basin case studies. Rural Society, 19(3), 211-228.
5. Idrobo, N., Mejía, D., \& Tribin, A. M. (2014). Illegal gold mining and violence in Colombia. Peace Economics, Peace Science and Public Policy, 20(1), 83-111.

6. Mabel, A. (2014). Hoedoafia, Benjamin Spears Ngmekpele Cheabu, Vida Korang. The Effects of Small Scale Gold Mining on Living Conditions: A Case Study of the West Gonja District of Ghana. International Journal of Social Science Research, Macrothink Institure, 2(1).

7. Ahmad, R. (2016). Dilema Penegakan Hukum Penambangan Mineral dab batubara tanpa izin pada pertambangan skala kecil. Jurnal Rechts Vinding, 5(3).

8. Ng, C. K. (2004). King of the Rivers: Mahseer in Malaysia and Region. Inter Sea Fishery Ltd., Selangor. Malaysia (170). 